\title{
The 64th Edinburgh International Film Festival
}

Schadenfreude - the largely unanticipated delight derived from the misfortunes of others. A delicious, exquisite pleasure. A little like being a Scotsman in London the day England crashed out of the World Cup. You know it's wrong but you just can't help savouring that little sip of another's pain. You gotta love the Germans for giving us a word like schadenfreude. Unfortunately, they never gave us a word for the opposite sensation so we'll have to make do with plain old envy. You know, like the feeling you get when one of your former classmates from film school gets his first feature film screened at the 64th Edinburgh International Film Festival. Annoyingly, the film in question, Gareth Edwards' Monsters is also damn good and has already won him a well-deserved Moët New Director award.

On paper Monsters owes more than a little to the JJ Abrams-produced Cloverfield (giant building-trashing monsters, night-vision action, goodlooking people in peril ...). Except it's actually good. And has protagonists you care about. And big monsters that inspire as much awe as they do dread. Unlike Cloverfield. It's a quietly intelligent film that uses the premise of giant building-trashing monsters to comment on cack-handed American imperialism, the War on Terror, and the response to Hurricane Katrina. The scenes where the heroes explore a devastated border town finding only one traumatised survivor echo the catastrophic destruction visited upon New Orleans or the unforgettable horror of $9 / 11$, while the night-vision battle that opens the film could be torn from the nightly news footage of Iraq or Afghanistan. Maintaining an atmosphere of barely controlled tension, the film subtly underplays its monstrous threat and, apart from the opening firefight, we see only hints of the creatures themselves for much of the running time (a tentacle here, a foot there), until the film's climax which manages to not only be scary but beautiful and magical.

It's a shame then that the rest of this year's Edinburgh International Film Festival programme isn't quite as magical. Now in its 64th year and increasingly showing signs of its age, the overwhelming impression made by this year's Festival is one of, well, niceness. Safety. This year's programme was safe. Nothing transgressive. Nothing cutting edge. Nothing to worry the kids or the cattle. The opening film, Sylvain Chomet's The Illusionist, was ... nice. Chomet, who directed the infuriatingly nice Belleville Rendez-Vous, has fashioned from an unrealised Jacques Tati script a gorgeous film about an aging stage magician touring Scotland which positively bleeds warmth and niceness into the cinema.

As ever there were some good films (Winter's Bone, The Secret in their Eyes, Yo, Tambien). There were some bad films (Chase the Slut, brilliantlove, Vacation!). Some mediocre films (Skeletons, Thelma, Louise and Chantal, almost every Brit flick). There was even a film where a timetravelling monk (played by Billy Zane) battled Greek zombies (the bonkers Evil in the Time of Heroes). The less said about German genius Werner Herzog's collaboration with David Lynch My Son, My Son What Have Ye Done, the better. Seriously, Werner Herzog and David Lynch? On the same film? Did that pairing at no time ring alarm bells somewhere?

One film that managed to tap into the darkness and magic of Edinburgh was Scottish werewolf movie Outcast. A mysterious pair of Irish travellers, mother and son Mary and Fergal (Kate Dickie and Niall Bruton), settle into ghetto life on one of Edinburgh's less salubrious high-rise estates where Fergal catches the eye of ballsy local beauty Petronella (the excellent Hanna Stanbridge) and romance blossoms. But as night falls, something is tearing the locals to pieces, Doctor Who's new assistant Amy Pond (Karen Gillan) among them, and two menacing strangers (Ciaran McMenamin and James Nesbitt) are closing in on Mary and Fergal ...

While it doesn't make a lick of sense and
Kate Dickie's accent is as dodgy as her nudie witch-dancing, Outcast is a ferocious little horror movie, a dark adult fairy tale where the deep, dark woods the beast stalks is our modern urban wasteland. Professional leprechaun James Nesbitt is positively unhinged as the werewolf hunter who's hairier than the beastie he's after and newcomer Hanna Stanbridge is gorgeous and feisty as the damsel who's perfectly able to save herself.

A grimy, doom-laden Western, The Last Rites Of Ransom Pride is almost a feminist revision of Sam Peckinpah. When outlaw Ransom Pride bites the dust, his lover Juliette Flowers (True Blood's Lizzy Caplan) heads down Mexico way to claim his body from voodoo priestess Bruja (NCIS eyecandy Cote de Pablo). Along the way she's aided by Ransom's callow younger brother Champ, aging buffalo soldier Sergeant, a pair of Siamese twins, and a kohl-eyed, shotgun-toting dwarf (the ever-brilliant Peter Dinklage) all the while trying to stay one step ahead of Ransom's biblically vengeful father, the Reverend (Dwight Yoakum), grizzled hired gun Shepherd (Kris Kristofferson) and a pair of murderous bounty hunters (Deadwood's W Earl Brown and an unrecognisable Jason Priestley channeling the spirit of 90210 co-star Shannon Doherty to play a twitchy psychopath). Dark and violent, The Last Rites Of Ransom Pride is an enjoyably brooding, sepia-tinged meditation on the passing of the Old West and the evil that men (and women) do where for once the gals ain't a civilizing influence with both Caplan and de Pablo being more than handy with gun or blade. And in case you haven't been paying attention, it has a shotgun-toting dwarf. What more does a film need?

While its frank, explicit sex scenes will ensure that Ashley Horner's brilliantlove will probably be the most controversial film of the Festival, brilliantlove just wasn't that brilliant. But I suppose mediocrecrapwithpointlessnudity would 
have been too literal a title. It's the steamy tale of two near-idiots who live in a garage and shag a lot. She's a taxidermist. He's a photographer. He gets drunk and leaves the holiday snaps of her vagina in the pub. Before you can say 'unbelievably obvious Brit-flick cliché', he's been discovered and seduced by the Art Establishment and she gets a bit miffed that now everybody has seen her mimsy. She leaves him and, left to his own devices, he relaxes by, ahem, 'dancing with himself'. While sporting a plastic bag over his head. There. l've just saved you 97 minutes of your life. No need to thank me, just use them wisely.

If you absolutely have to see one film this year however, featuring the singular joys of auto-erotic asphyxia, why not make it World's Greatest Dad? Directed by Bobcat Goldthwait, World's Greatest Dad is a pitch-black comedy which follows sadsack teacher and failed writer Robin Williams as he turns his teenage porn addict son's masturbatory mishap into a less embarrassing suicide, even going so far as to fake a suicide note and accompanying confessional journal which give the frankly despicable little pervert depth and a tortured nobility in the process. As events spiral beyond his control, Williams finds himself having to tell bigger and bigger lies and also gets a taste of the respect and success he's always dreamed of. It may not be as funny or as taboobusting as it thinks it is but the film does have some pantwettingly funny moments and features Robin Williams' best performance in 20 years.

Based on a true story, Austria's The Robber is a breathless, kinetic crime thriller $w h \circ$ s e existentialist protagonist, a marathon-running bank robber, seems to be in constant motion, propelled by fate, circumstances and his own single-minded compulsions, towards a doom that's as avoidable as it is inevitable. Andreas Lust is magnetic in the title role and the chemistry between him and love interest Franziska Weisz is palpable, hinting at redemption even as events close in on them. The bombastic epic Henry of Navarre covered much the same ground as the 1994 La Reine Margot, Gravity gave us a Teutonic take on Fight Club as a wage slave (the spitting image of Jimmy Carr) discovers the macho joys of crime and ultra-violence, and, while visually stunning, French Western Lucky Luke gave us a faithfully ludicrous (talking horse and all) and not very funny adaptation of Maurice De Bevere's comic strip cowboy who can shoot faster than his own shadow.

Proving there's a reason why most underground filmmakers never make it overground, John Michael McCarthy's Cigarette Girl takes one good idea (it's the future and cigarettes are outlawed, available only in the dodgy part of town where they change hands for $\$ 63$ a pack) and a charismatic lead (feisty Goth babe Cori Dials) and builds a film around them that is little more than an excuse to pour the statuesque Dials into 'a corset that could stop a bullet or start a conversation' and have her run from one posing opportunity to another as she cleans up the mean streets of the near-future Memphis.
A triumph of bad acting, bad writing and lacklustre direction, the only possible reason for watching this movie is if you enjoy watching tattooed, pistol-packing Goth chicks strike a pose in corsets and fetish heels.

Which is pretty much why I watched it.

Far more rewarding was the Argentinian Oscar-winner The Secret in Their Eyes, a stylish, intelligent meditation on guilt, loss, regret and unrequited love masquerading as a murder-mystery. A retired investigator (the always excellent Ricardo Darin) decides to write a book about the case that's haunted him for 25 years, the rape and murder of a young bride, a crime where the murderer escaped justice thanks to some dodgy government ties. His research brings him back into contact with his former boss (the sparkling Soledad Villamil) and the still-grieving husband of the murdered girl (Pablo Rago) as he tries to bring closure to the case. Working equally well as a police procedural as it does a middle-aged romance, The Secret in Their Eyes is a stunning, beautiful film which will linger in the memory long after the likes of brilliantlove has gasped its last.

\section{David Watson}

\section{DOI: 10.3399/bjgp10X515278}

Monsters, directed by Gareth Edwards. 